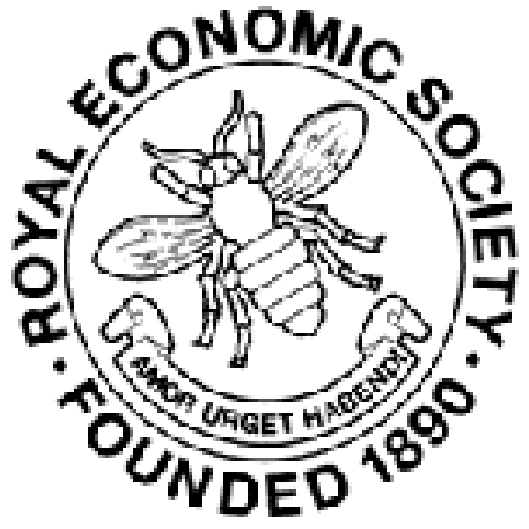

Railways and Waterways in Germany

Author(s): Gustav Cohn

Source: The Economic Journal, Vol. 4, No. 15 (Sep., 1894), pp. 541-545

Published by: Wiley on behalf of the Royal Economic Society

Stable URL: http://www.jstor.org/stable/2955746

Accessed: 11-06-2016 02:42 UTC

\title{
REFERENCES
}

Linked references are available on JSTOR for this article:

http://www.jstor.org/stable/2955746?seq=1\&cid=pdf-reference\#references_tab_contents You may need to log in to JSTOR to access the linked references.

Your use of the JSTOR archive indicates your acceptance of the Terms \& Conditions of Use, available at

http://about.jstor.org/terms

JSTOR is a not-for-profit service that helps scholars, researchers, and students discover, use, and build upon a wide range of content in a trusted digital archive. We use information technology and tools to increase productivity and facilitate new forms of scholarship. For more information about JSTOR, please contact support@jstor.org.

Royal Economic Society, Wiley are collaborating with JSTOR to digitize, preserve and extend access to The Economic Journal 


\section{Railways and Waterways in Germany}

Much that has appeared recently in the Economic Journal has brought home to me the expediency of personally clearing up misunderstandings, and correcting misrepresentations, of my views. Beyond a short article on the 'Railway Policy of Prussia,' published in the Journal of Political Economy of Chicago University, March, 1893, I have hitherto never addressed myself to an English-reading public on the subject of the economics of the railway. This is not inconsistent with the fact that I published some years ago a work on the history and situation of English railway policy (Untersuchungen. über die Englische Eisenbahnpolitik, 1874, 1875, 1883, 3 Bde.). The work was written not for England, but for Germany, and if, besides its generally scientific purport, it had any practical aim, it was not to instruct the English respecting any part of their legislation and policy, but to derive some lessons for the railway policy of Germany. Such is the now established practice of the age, continually to be drawing comparisons between the institutions of different States and endeavouring to acquire knowledge by way of this comparative political science.

The scientific and practical, as well as the moral and political, worth of this comparative method consists in freeing the mind, when contemplating political situations, whether in one's own or a foreign land, from that very defect which has been lately imputed to me in this journal, that of ' patriotic bias.' I do not in the least contend that I am free from it, but I do maintain that I have always striven to be so. For all good scientific method must start with establishing such objective truths as are demonstrable to every person of sound discernment. It must therefore root out all subjective accretions as so many weeds, and, if the end is not attained, it must at least recognise it as a duty continually to be approximating to it. True, it is no easy matter to judge fairly how far each political writer has succeeded in reaching this aim. For as matters are at present, and owing to divergence in the views of different nations, it may easily happen that any word of blame bestowed by German writers on English institutions or writings, as well as any mark of appreciation conferred by them on German institutions, is regarded in the eyes of Englishmen as a consequence of their patriotic prejudice, no matter how, in other respects, they praise England or blame Germany. English writers experience similar treatment with respect to Germany. But what in opposition to mere journalistic party-wrangle every serious student has a right to expect from his like is, that he should be attentively read before he is blamed.

Thus, with respect to my praising the procedure of parliamentary inquiries in England in one of my latest articles on English railway legislation, it has been remarked that I do 'recognise at least one 
thing as good in a country where not all are State officials.' Now I am not aware, that in criticising individualistic tendencies in English railway policy I gave vent anywhere to an enthusiasm for a socialistic organisation of national economy, i.e. for a condition of things in which all are State officials. But if by this the German Constitution is meant, the opinion betrays an uncommon degree of ignorance of German affairs. I am in truth of opinion that it is possible to be a sincere admirer of a great many English public institutions and yet find much to criticise, as I have done. In the same way one may be convinced of the necessity of reform in many features of German public life, yet none the less recognize in certain of them the advantages and superiority of Germany as compared with other countries. For it is of the essence of scientific criticism of public affairs and institutions, never wholly and altogether to praise or blame, but to distinguish particulars, and to show of how many parts the whole of a political organism is composed. It is just by such procedure that it contrasts with the customary national instincts of the great majority in their mode of dealing with politics.

However, my present intention is to write, not on the railway politics of England, but on certain features of those of Germany. And to illustrate what I have said, I will present, as calling for criticism, certain features in a system of transport (and its connexion with the State institutions to which it belongs) of which I essentially approve.

The general procedure, motives and results of the railway policy of Prussia during the last decade I have set forth in the above-named article in the Journal of Political Economy. I there laid stress on the following:- 'For a century Germany has regarded the individualism of England as a model for imitation; to-day the legislation of England assumes more and more the characteristics which the English have for a long time regarded as distinctly Continental, or German. This fact remains, by whatever name the tendency of the recent legislation in England may be designated, whether it is called socialistic, Statesocialistic, or bureaucratic.' In the face of this approximation to the economic and social policy of the Continent, it is no longer possible for England to repudiate what she takes for her example, as something exotic and alien, and therefore proving nothing.

On these grounds it is equally instructive to look at both the bright and the dark sides. What I wish to draw attention to is not exactly a dark side, yet it tends to become so, although it is connected with one of the great successes of the Prussian State-system. The Government of Prussia has not only succeeded in buying up the railways from the hands of chartered companies, in open market and at a liberal buying price, without any disturbance of Government credit, but the financial result of the anrual net returns of the railways was also so favourable, that the railway administration, after paying interest on its loancapital, handed over, during the period 1882-92, $£ 42,000,000$ towards abolishing the National Debt and for general needs of the State. The 
net returns averaged $5 \frac{1}{2}$ per cent., the interest on Government loans being $3 \frac{1}{2}$ per cent. This financial result, exceeding all expectations, and contrasting with that experienced on a smaller scale after the purchase of the telegraphs by the English Government, was not brought about by a narrow fiscal tariff-policy; on the contrary it went hand in hand with considerable reductions in passenger fares, and especially in the rates for goods transport. Further reductions were suspended by the defraying of general State expenditure, for which inadequate provision had been made in developing the system of taxation.

Meanwhile the conviction, expressed by J: R. MacCulloch and Wilhelm Roscher immediately after Rowland Hill's postal reform, has been ever gaining ground. In the words of Roscher, 'Rowland Hill's postal reform is the removal of a tax laid on commerce which must now be borne by others, although it was just, gentle and customary.' 1

Now just as the English Post Office has managed, in spite of this thoroughgoing reduction in the cost of postage, to realise during recent years an annual net surplus of $£ 3-4,000,000$, so may we see in the surpluses of the Prussian railway administration an analogous kind of taxation, and one which affects those strata of the population which are most able to pay taxes. Looked at with respect to imperial and local taxation as a whole, this kind of taxation is a just complement to the various kinds of imposts maintained by the daily needs of the working classes (such as the imperial tax on salt, duty on corn, petroleum, coffee, and the like), which nevertheless, in the present position of the German fiscal system, and of growing needs, especially those of the State machinery, cannot be dispensed with.

A striking contrast is presented when we turn from this financial position of the State railways to the relation of the State administration to the waterways. Here I must expatiate a little, because this part of our system of transport is so entirely different from English usage, and because of the misunderstandings which have lately arisen in connection with the work done on the waterways of Germany. ${ }^{2}$

The German rivers, the natural waterways of inland navigation, have for centuries been sources of trouble to the national economy. They have been a mirror of the political rents and dissensions of ages. The fight for the unity of Germany showed itself in the efforts to free German rivers from the fiscal barriers imposed by each little sovereignty. Those efforts lasted from the beginning of this century to the establishment of the German Empire in 1871. Article 54 of the new

\footnotetext{
1 Grundriss zu Vorlesungen ïber die Staatswirthschaft nach geschichtlicher Methode, p. 90.

2 Readers who wish to devote special attention to the subject are referred to an excellent work recently published by Franz Ulrich, Staffeltarife und Wasserstrassen. (Berlin, 1894).
} 
Constitution removed all burdens on inland water-traffic, except such as went to pay for keeping up that traffic. Even these were limited to cover necessary expenses: in the case of natural waterways, for the use of special conveniences; in that of canals, for maintenance and repairs of the same. The actual policy of the last twenty years has overshot the tendency of this Article 54. Hence precisely the opposite result to that of the railways has come about. Plant erected at great cost by State and communes for the convenience of navigation (harbours, locks, quays, \&c.) has been set gratuitously at the service of traffic, or at best in return for tolls mostly inadequate to pay for their maintenance, let alone any interest on loan-capital. These financial methods have been extended from rivers to canals and canalised rivers. According to a report drawn up for the fifth International Congress of Inland Navigation at Paris in 1892, the German waterways, during the ten years 1881-90, cost the German Governments on an average $26,000,000$ marks per annum, against a revenue by tolls of $2,000,000$. To this must be added the considerable, though not precisely calculable, item of interest on borrowed capital for artificial waterways, as well as the harbour outlay in natural waterways, and the sums spent by communes, railway boards, \&c., for harbours, wharves, warehouses. For Prussia alone the following figures: are established. During the years 1880-90, 183,000,000 marks were expended in river and canal conservancy, bridges, \&c. Besides this; the Prussian Government has lately turned its attention to the construction of artificial waterways. $184,000,000$ marks have been devoted to canals already constructed, or in course of construction. This, at a yearly rate of 18.3 millions, brings the former figure up to an annual expenditure of 36.7 millions, against two millions of receipts. Thus nearly the entire surplus of the railway administration is swallowed up by the waterways.

This discrepancy of procedure in rail and water transit reminds us, as the author of the book I have above cited appositely remarks, of the story of Cinderella. The State railways are Cinderella, who must not only keep herself, but must also work for other branches of the State administration, and gets scolded into the bargain if in any year the surplus is not big enough; whereas the waterways are the spoilt daughters to whom Cinderella's earnings are heedlessly handed over, and who, decked in feathers not their own, make free with money not their own.

Why is this? Such discrepancy of treatment is due only to the distorted view taken about the nature of waterways. According to this view it is the function of the State, or other corporate body, to provide waterways as nearly free of charge as possible for traffic, whether they be natural or artificial, costly or not, and to cover the resulting deficit by public means. But by what right? By no better right, nay, by less right, than can be claimed for free railway commu, nication at public cost. For traffic by inland navigation has so deve. 
loped itself of recent years in Germany, as to benefit more especially the larger firms ; and that these should obtain gifts at public expense is a most perverted form of communism, since it compels the great mass of taxpayers to make sacrifices in the interest of the wealthy minority. Contrariwise, in the railway traffic, in so far as it is passenger traffic, there is a far more adequate provision for the interests of the majority.

But it is quite wrong not to take into account this financial privilege of the waterways, when discussing the relative efficiency of rail and water. Such comparison would only be legitimate where railways and waterways were left alone, to prove their real efficiency unaided by any State subsidy. This is the advantage of the English system. The developments of the last sixty years in England, the growing superiority for goods traffic of railways over canals; and even over the coasting trade, constitutes a protracted experience little favourable to the merits of the waterways. It leaves open to-day only such questions as (1) Has the rule of English railway companies been strong enough to find means to suppress artificially the natural superiority of the waterways? (2) Is it only that England has not kept pace with the new technical developments in continental inland navigation ? (3) Is it true, as asserted by the Continental advocates of canals, that because of those developments the age of canals lies in the future and not in the past? England too, as we know, has for the last ten years committed herself to experimenting in canals, the last great experiment being the Manchester Ship Canal. The events attending this enterprise, both in the past and the future, are instructive for our inquiry. There was in particular a remarkable approximation to Continental events in the necessity, which very soon arose, for the intervention, on behalf of the undertaking, of the Manchester Town Council and its finances. But the time when it will be possible to see clearly is not yet.

Gustav Cohn

(Translated by C. A. Folex)

\section{A Family of Metayers of the Commune of Reggio Emilia (ItTALY)}

I OUGHT to premise that I have no very high opinion of the scientific utility of the so-called family budgets on the Le Play system. Convinced follower though I am of the positive historical method of observation in the study of social phenomena, I do not see why that particular form of observation should be the best. For in the selection of the family to be described as representing the prevalent type in a given locality, too great freedom is left to the judgment of the observer, on whose discretion alone is based the determination of the type. 